\title{
WYKORZYSTANIE METODY IDENTYFIKACJI PODEJŚCIA DO STRATEGII W BADANIACH WYBRANYCH PRZEDSIĘBIORSTW
}

Z a r y s t r e ś c i: Zarządzanie strategiczne to wytyczanie sposobów realizacji długoterminowych celów przedsiębiorstwa. Najczęściej głównym jego celem jest osiągnięcie sukcesu rynkowego. Musi więc opierać się zarówno na wytyczonych przez organizację wyznacznikach tego sukcesu, jak i na zewnętrznych czynnikach tworzących otoczenie rynkowe. Duże znaczenie mają przy podejmowaniu takich decyzji aktualne informacje z rynku - należy znać ich dobre źródło i weryfikować je za pomocą wiedzy i kompetencji. Nigdy jednak nie będziemy mieli twardej analizy wskazującej na szanse powodzenia danego działania. Jeżeli nie podejmujemy próby zdefiniowania obecnego stanu firmy pod kątem decyzji, jakie podejmują zarządzający, to nie będzie możliwe wykreowanie obiektywnego rozwiązywania mającego na celu rozwój organizacji. Celem artykułu jest zbudowanie metody, dzięki której będzie można zidentyfikować sposób myślenia o podejściu do strategii oraz wyciągnąć wnioski z przeprowadzonej analizy, aby można było podejmować świadome decyzje.

S ł o w a k 1 u c z o w e: zarządzanie strategiczne; strategia; zarządzanie przedsiębiorstwem; przedsiębiorstwo; metoda identyfikacji podejść do strategii.

Klasyfikacja JEL: L21.

Adres do korespondencji: Marcin Jasiński, Uniwersytet Ekonomiczny we Wrocławiu Wydział Zarządzania, Informatyki i Finansów, Katedra Strategii i Metod Zarządzania, ul. Komandorska 118/120,53-345 Wrocław, e-mail: jasinski.marcin@o2.pl. 


\section{WSTĘP}

O ile literatura przedmiotu zarządzania strategicznego w obszarze strategii i metod zarządzania w krajowym i zagranicznym jest bogata, o tyle literatura w zakresie odpowiedniego wyboru podejścia do strategii danego przedsiębiorstwa czy wyboru odpowiedniego narzędzia realizacji takiej strategii jest praktycznie znikoma. W związku z tym pojawiła się luka poznawcza i tym samym badawcza wymagająca głębszych rozważań w zakresie wyborów strategicznych, która zainspirowała autora do podjęcia działań mających na celu zaprojektowanie narzędzia, które będzie wspierać podejmowanie decyzji strategicznych w przedsiębiorstwach.

Celem artykułu jest przedstawienie wyników badania, dzięki któremu proponowana metoda identyfikacji podejścia do strategii w zarządzaniu lub szerzej w zarządzaniu strategicznym znajdzie swoje potwierdzenie w praktyce gospodarczej.

Zdaniem autora często dzieje się tak, że wielu menedżerów w przedsiębiorstwach nie jest świadomych tego, że zidentyfikowane w literaturze podejścia do zarządzania strategicznego są przez nich stosowane w praktyce. Skutkiem tego jest to, że wiele decyzji strategicznych w przedsiębiorstwie nie jest spójne z założonym celem oraz z jego realizacją. Brak związków między celem a profilem firmy w danej branży może mieć negatywny skutek. Błędnie sformułowane cele mogą powodować rozproszenie i suboptymalizację działań oraz problemy z dostosowaniem się organizacji do zmian w otoczeniu. Zasadne jest, aby decyzje, tak ważne dla przedsiębiorstwa, poparte były narzędziem, które w pierwszym etapie zdiagnozowałoby dane przedsiębiorstwo oraz klasyfikowało do konceptu myślenia o strategii w zarządzaniu strategicznym. Diagnoza przedsiębiorstwa dzięki tak przeprowadzonej analizie byłaby podstawą do podjęcia decyzji dotyczących celów długoterminowych przedsiębiorstwa.

W zarządzaniu strategicznym możliwe jest wyodrębnienie okresów dominacji w praktyce i teorii zarządzania określonych sposobów myślenia o strategii [Niemczyk, 2013, s. 9]. Zidentyfikowanie tych sposobów, wiedza o rozwoju podejść do strategii mogą być pomocne w odczytaniu rzeczywistych źródeł wyborów strategicznych, realnych kontekstów działania, wyjaśnieniu realnych powodów osiągania sukcesu przez firmy funkcjonujące w danym czasie historycznym.

W związku z tym wyróżnić można podejście klasyczne oraz współczesne do strategii. 
Do podejść klasycznych zaliczyć można następujące podejścia do strategii:

- planistyczne,

- pozycyjne,

- zasobowe.

Do podejść współczesnych zaliczamy z kolei:

- innowacyjno-przedsiębiorcze,

- sieciowe.

Klasyczne podejścia do strategii zdominowały zarządzanie strategiczne przez ostatnie niemalże 70. lat. Pojawiły się w międzyczasie inne sposoby myślenia o strategii. Niemniej jednak wymienione podejścia skutecznie odpierały ataki i utrzymywały się na swojej pozycji. Natomiast nowoczesne myślenie o podejściu do strategii z coraz większą siłą wkracza w życie głównych strategów.

\section{KRÓTKA CHARAKTERYSTYKA METODY IDENTYFIKACJI PODEJŚĆ DO STRATEGII}

W literaturze przedmiotu możemy wskazać szereg narzędzi w przestrzeni wszystkich podejść do strategii mających na celu ocenić i zaprojektować pozycję strategiczną, ocenić możliwości rozwojowe przedsiębiorstwa pod kątem portfela produktów i technologii - metody portfelowe, jak: macierz Boston Consulting Group, macierz Arthura D. Little'a (ADL) macierz Hofera (jako udoskonalenie macierzy BCG i ADL), macierz McKinsey'a - General Electric; diagnoza otoczenia zewnętrznego - mapy grup strategicznych, analiza PEST, analiza otoczenia konkurencyjnego (pięć sił) M.E. Portera; całościowa ocena potencjału strategicznego przedsiębiorstwa - bilans strategiczny przedsiębiorstwa, analiza kluczowych czynników sukcesu, analiza łańcucha wartości. Należy także wspomnieć o metodach nie objętych - ze względu na ich złożoność - powyższą klasyfikacją: to metody scenariuszowe (mniej popularne, aczkolwiek zalecane w aktualnych warunkach turbulentnego otoczenia).

W audycie strategicznym wykorzystywane jest jedno z najpopularniejszych narzędzi: analiza SWOT i jej rozszerzona wersja: TOWS/SWOT [Gierszewska, Romanowska, 2009, s. 10]. Jednak zdaniem autora żadna z powyższych metod nie pozwala zakwalifikować przedsiębiorstwa do danego podejścia do strategii, a jedynie umożliwia wykorzystanie danej metody z danego podejścia. Pytanie brzmi: czy przedsiębiorstwa wykorzy- 
stujące jedną z powyższych metod powinny ją stosować, nie znając tak naprawdę swojego miejsca w zarządzaniu strategicznym lub szerzej w podejściu do strategii?

W związku z powyższym Autor proponuje prostą metodę identyfikacji podejść do strategii. Głównym jej celem jest przede wszystkim skojarzenie danego przedsiębiorstwa $\mathrm{z}$ właściwym dla niego podejściem do zarządzania strategicznego. Następnie dzięki uzyskanym wynikom będzie prawdopodobnie można ocenić, czy ta przynależność jest zgodna z ich profilem firmy w danym sektorze działania.

Na podstawie wybranych cech podejść do strategii w poniższej tabeli 1 główny strateg (prezes, dyrektor zarządzający lub osoba odpowiedzialna za strategię w danym przedsiębiorstwie lub instytucji) udziela odpowiedzi. Ankieta zawiera 25 cech, które dotyczą zarządzania strategicznego.

Wymienione cechy reprezentują poszczególne podejścia do strategii każde posiada po 5 kluczowych cech. Wymagane jest, aby cecha, która przynależy do badanego przedsiębiorstwa została przypisana $\mathrm{w}$ taki sposób, aby suma punktów - wag wszystkich wybranych cech dała w sumie 100. Następnie każda wybrana cecha powinna być oceniona w skali od 1 do 5, gdzie 1 - najgorzej oceniam daną cechę, 5 - najlepiej oceniam daną cechę z punktu widzenia badanego przedsiębiorstwa. Obie dane po pomnożeniu dają nam wynik, którym jest wartość ważona, która następnie przedstawiona będzie w postaci wskaźnika procentowego. Dzięki temu przedsiębiorstwo zostanie zakwalifikowane do jednego lub wielu podejść do strategii. Ważnym elementem badania jest to, że przedsiębiorstwo waży i ocenia wszystkie cechy lub tylko takie, które są dla niego właściwe. Dlatego też wynik będzie przyporządkowywał firmę do danego podejścia lub podejść, a nie tylko oceniał jedno podejście do strategii.

Dodatkowo respondenci zostaną poproszeni o wypełnienie krótkiej metryczki dotyczącej:

- zasięgu firmy: lokalna, krajowa, międzynarodowa, globalna,

- wielkości firmy: mała, średnia, duża,

- branży: handel, produkcja, usługi,

- relacji: B2B, B2C. 
Tabela 1. Metoda identyfikacji podejść do strategii

\begin{tabular}{|c|c|c|c|c|}
\hline LP. & $\begin{array}{l}\text { Cechy zarządzania strategicznego } \\
\text { w przedsiębiorstwie }\end{array}$ & Waga & $\begin{array}{l}\text { Ocena } \\
{[1 \text { do } 5]}\end{array}$ & $\begin{array}{l}\text { Wartość } \\
\text { ważona }\end{array}$ \\
\hline 1 & Wyznaczanie długoterminowych celów & & & 0 \\
\hline 2 & $\begin{array}{l}\text { Menedżeryzm - Menedżer - główny strateg, prezes } \\
\text { firmy określa poziom zysku oraz sposób jego } \\
\text { osiągnięcia }\end{array}$ & & & 0 \\
\hline 3 & $\begin{array}{l}\text { Powierzenie zasobów firmy (zasoby ludzkie, mate- } \\
\text { rialne, finansowe) menedżerom }\end{array}$ & & & 0 \\
\hline 4 & $\begin{array}{l}\text { Celem firmy jest maksymalizacja zysku ekonomicz- } \\
\text { nego }\end{array}$ & & & 0 \\
\hline 5 & $\begin{array}{l}\text { Marżowość firmy uzależniona od popytu na dany } \\
\text { produkt. Wysokość marży wynika z relacji między } \\
\text { popytem a podażą na dany zasób }\end{array}$ & & & 0 \\
\hline 6 & $\begin{array}{l}\text { Celem firmy jest osiąganie zysku wyższego niż } \\
\text { przeciętny w branży }\end{array}$ & & & 0 \\
\hline 7 & $\begin{array}{l}\text { Marża wynika z udziału firmy w danym sektorze czy } \\
\text { rynku }\end{array}$ & & & 0 \\
\hline 8 & $\begin{array}{l}\text { Wykorzystywanie różnych metod analizy sektora, } \\
\text { rynku: } 5 \text { sił M.E. Portera, SWOT, BCG, ADL }\end{array}$ & & & 0 \\
\hline 9 & $\begin{array}{l}\text { Wykorzystywanie dywersyfikacji portfelowej (Teoria } \\
\text { portfelowa) }\end{array}$ & & & 0 \\
\hline 10 & Walka konkurencyjna o udziały w rynku & & & 0 \\
\hline 11 & $\begin{array}{l}\text { Zarządzanie poprzez rozwój kluczowych kompe- } \\
\text { tencji w celu efektywnego wykorzystania zasobów } \\
\text { firmy }\end{array}$ & & & 0 \\
\hline 12 & $\begin{array}{l}\text { Maksymalizacja zysku ekonomicznego poprzez } \\
\text { zbiór odpowiednich kompetencji }\end{array}$ & & & 0 \\
\hline 13 & $\begin{array}{l}\text { Strategia zarządzania oparta na układzie: kompeten- } \\
\text { cja - rynek }\end{array}$ & & & 0 \\
\hline 14 & $\begin{array}{l}\text { Kapitał intelektualny jest funkcją tworzenia długo- } \\
\text { okresowej wartości dla przedsiębiorstwa }\end{array}$ & & & 0 \\
\hline 15 & $\begin{array}{l}\text { Zasoby firmy wykorzystywane są do budowania } \\
\text { przewagi konkurencyjnej }\end{array}$ & & & 0 \\
\hline
\end{tabular}


Cd. tab. 1

\begin{tabular}{|c|c|c|c|c|}
\hline LP. & $\begin{array}{l}\text { Cechy zarządzania strategicznego } \\
\text { w przedsiębiorstwie }\end{array}$ & Waga & $\begin{array}{l}\text { Ocena } \\
{[1 \text { do } 5]}\end{array}$ & $\begin{array}{l}\text { Wartość } \\
\text { ważona }\end{array}$ \\
\hline 16 & Innowacyjne zarządzanie przedsiębiorstwem & & & 0 \\
\hline 17 & Aktywne zarządzanie ryzykiem & & & 0 \\
\hline 18 & $\begin{array}{l}\text { Marża wynikająca z nadwyżki z tytułu innowacji - } \\
\text { innowacji rozumianej jako pojawienie się nowych } \\
\text { produktów, nowych źródeł podaży, nowych typów } \\
\text { organizacji }\end{array}$ & & & 0 \\
\hline 19 & $\begin{array}{l}\text { Niszowy charakter zarządzania koncentracji na } \\
\text { rynek }\end{array}$ & & & 0 \\
\hline 20 & $\begin{array}{l}\text { Zarządzanie firmą poprzez szukanie „błękitnych } \\
\text { oceanów” }\end{array}$ & & & 0 \\
\hline 21 & $\begin{array}{l}\text { Oportunistyczne motywy postępowania przy wyzna- } \\
\text { czaniu celów i sposobów działania }\end{array}$ & & & 0 \\
\hline 22 & Zarządzanie kontraktami & & & 0 \\
\hline 23 & $\begin{array}{l}\text { Marża wynika z nadwyżek uzyskanych dzięki } \\
\text { kontraktom sieciowym. Jednorazowe kontrakty } \\
\text { zwiększają koszty firmy }\end{array}$ & & & 0 \\
\hline 24 & Tworzenie sieci międzyorganizacyjnych & & & 0 \\
\hline 25 & $\begin{array}{l}\text { Firma nakierowana na zmniejszanie kosztów trans- } \\
\text { akcyjnych }\end{array}$ & & & 0 \\
\hline & WYNIK KOŃCOWY & 100 & & 0 \\
\hline
\end{tabular}

Źródło: opracowanie własne.

\section{WYNIKI BADANIA STRATEGII \\ PRZY POMOCY METODY IDENTYFIKACJI PODEJŚĆ DO STRATEGII}

Przygotowana metoda diagnozy została wykorzystana do przebadania 35 przedsiębiorstw reprezentowanych przez 35 studentów studiów MBA na Uniwersytecie Ekonomicznym we Wrocławiu po to, by zweryfikować jej założenia i sprawdzić praktyczną przydatność. Badanie odbyło się 10.04.2015 roku. Ankiety zostały wypełnione przez samych studentów, 
czyli osoby odpowiedzialne za zarządzanie na szczeblach średnich i powyżej w firmach dolnego śląska i ościennych województw.

Przeprowadzone badanie przedstawia obraz myślenia o strategii. Pokazuje on, że ponad $30 \%$ przedsiębiorstw reprezentuje podejście planistyczne. Następne $21 \%$ wykazało cechy właściwe dla podejścia zasobowego oraz po $19 \%$ dla podejść sieciowych i pozycyjnych. Natomiast podejście innowacyjne uzyskało wynik $11 \%$ (rys. 1.).

Taki układ wyników może świadczyć, że koncepcja planistyczna jest bardzo istotna. Niemniej jednak ważnym sygnałem jest fakt, że podejście sieciowe przesuwa się na czołowe pozycje w myśleniu o strategii. Reasumując: nadal podejścia klasyczne przeważają na współczesnymi w stosunku 70:30.

Ponadto inne badanie przeprowadzone przez Marcina Jasińskiego [Jasiński, 2015, s. 7] na próbie 66 przedsiębiorstw oraz instytucji z różnych branż, które odbyło się w 2014 roku w okresie od maja do września, potwierdziło wyniki obecnego projektu, że ponad $24 \%$ przedsiębiorstw reprezentuje podejście planistyczne, następne $22 \%$ wykazało cechy właściwe dla podejścia pozycyjnego, a $20 \%$ innowacyjnego. Natomiast podejście sieciowe oraz zasobowe uzyskało odpowiednio poziom $18,22 \%$ i 15,88\%.

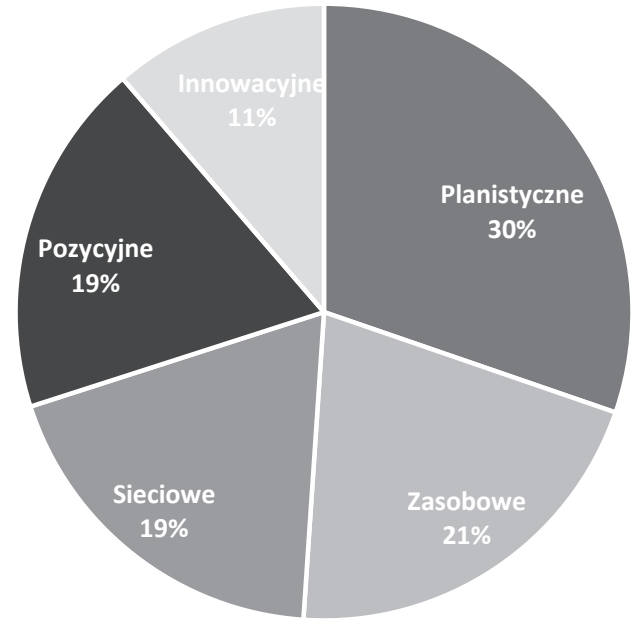

Rys. 1. Struktura odpowiedzi podejść do strategii w badaniach identyfikacji podejść do strategii

Źródło: opracowanie własne na podstawie wyników badań przeprowadzonych w przedsiębiorstwach reprezentowanych przez studentów MBA na Uniwersytecie Ekonomicznym we Wrocławiu. 
Wśród przedsiębiorstw dużych znaczący wpływ na kształtowanie strategii generują podejścia klasyczne. Badanie wskazuje, że bardzo istotnym elementem $\mathrm{w}$ przedsiębiorstwach średnich jest myślenie sieciowe, które zdecydowanie dominuje w tych firmach. W wymienianych grupach przedsiębiorstw znikome wydaje się znaczenie innowacyjnego myślenia o strategii. Zaobserwować można również, że im mniejsza firma, tym znaczenie zasobów dla firmy jest mniejsze, natomiast im większa firma, tym myślenie w kategoriach sieci staje coraz ważniejsze.

Tabela 2. Struktura odpowiedzi podejść do strategii względem wielkości zatrudnienia

\begin{tabular}{|c|c|c|c|c|c|}
\hline $\begin{array}{r}\text { Rodzaj podejścia } \\
\text { do strategii } \\
\text { zatrudnionych }\end{array}$ & $\begin{array}{c}\text { Planistycz- } \\
\text { ne }\end{array}$ & $\begin{array}{c}\text { Pozycyj- } \\
\text { ne }\end{array}$ & $\begin{array}{c}\text { Zasobo- } \\
\text { we }\end{array}$ & $\begin{array}{c}\text { Innowacyj- } \\
\text { ne }\end{array}$ & $\begin{array}{c}\text { Siecio- } \\
\text { we }\end{array}$ \\
\hline Duża & $27,73 \%$ & $17,08 \%$ & $25,07 \%$ & $10,82 \%$ & $19,30 \%$ \\
\hline Średnia & $20,59 \%$ & $18,65 \%$ & $22,25 \%$ & $13,67 \%$ & $24,84 \%$ \\
\hline Mała & $32,50 \%$ & $19,05 \%$ & $19,42 \%$ & $11,08 \%$ & $17,96 \%$ \\
\hline Suma końcowa & $30,28 \%$ & $18,64 \%$ & $20,79 \%$ & $11,32 \%$ & $18,98 \%$ \\
\hline
\end{tabular}

Źródło: opracowanie własne na podstawie wyników badań przeprowadzonych wśród studentów MBA na Uniwersytecie Ekonomicznym we Wrocławiu.

Większość badanych przedsiębiorstw, bo aż 64\%, prowadzi swoją sprzedaż lokalnie oraz krajowo. Pokrywa się to z koncepcjami planistycznymi oraz zasobowymi. Jedynie przedsiębiorstwa prowadzące sprzedaż krajową, które stanowią prawie 48\%, skłaniają się do myślenia sieciowego. Firmy globalne i międzynarodowe łączą podejścia klasyczne ze współczesnymi, ponieważ jak pokazuje tabela 3 , myślenie planistyczne oraz sieciowe zdecydowanie przeważa i jest pewnym potwierdzeniem poprzednich badań, gdzie firmy o dużym zasięgu terytorialnym przeplatają w swoich działaniach podejście sieciowe oraz planistyczne. 
Tabela 3. Struktura odpowiedzi podejść do strategii względem zasięgu firmy

\begin{tabular}{|c|c|c|c|c|c|}
\hline $\begin{array}{r}\text { Rodzaj podejścia } \\
\text { do strategii }\end{array}$ & Planistyczne & Pozycyjne & Zasobowe & Innowacyjne & Sieciowe \\
\hline Zasięg firmy & & & & & \\
\hline Globalna & $37,70 \%$ & $15,46 \%$ & $14,29 \%$ & $13,99 \%$ & $18,56 \%$ \\
\hline Międzynarodowa & $30,35 \%$ & $16,85 \%$ & $21,77 \%$ & $12,61 \%$ & $18,43 \%$ \\
\hline Krajowa & $26,53 \%$ & $22,92 \%$ & $19,77 \%$ & $10,22 \%$ & $20,56 \%$ \\
\hline Lokalna & $38,52 \%$ & $9,98 \%$ & $25,08 \%$ & $11,18 \%$ & $15,24 \%$ \\
\hline Suma końcowa & $30,28 \%$ & $18,64 \%$ & $20,79 \%$ & $11,32 \%$ & $18,98 \%$ \\
\hline
\end{tabular}

Źródło: opracowanie własne na podstawie wyników badań przeprowadzonych wśród studentów MBA na Uniwersytecie Ekonomicznym we Wrocławiu.

Kolejną ciekawą i bardziej skonsolidowaną analizą jest podział firm na 3 sektory, czyli handel, produkcję oraz usługi. Dane wskazują pewne bardzo podobne zależności, że dla firm handlowo-usługowych w obecnym, jak i poprzednim badaniu oprócz powszechnie przyjętego planistycznego podejścia coraz bardziej znaczący staje się wpływ sieci w tych przedsiębiorstwach, które osiągają niemalże $20 \%$ udziału w podejmowanych decyzjach.

Tabela 4. Struktura odpowiedzi podejść do strategii względem branży firmy

\begin{tabular}{|c|c|c|c|c|c|}
\hline $\begin{array}{r}\text { Rodzaj podejścia } \\
\text { do strategii }\end{array}$ & Planistyczne & Pozycyjne & Zasobowe & Innowacyjne & Sieciowe \\
\hline Branża firmy & & & & & \\
\hline Handel & $34,39 \%$ & $21,32 \%$ & $13,99 \%$ & $11,47 \%$ & $18,84 \%$ \\
\hline Produkcja & $33,11 \%$ & $13,74 \%$ & $20,80 \%$ & $13,47 \%$ & $18,88 \%$ \\
\hline Usługi & $24,72 \%$ & $20,49 \%$ & $26,17 \%$ & $9,45 \%$ & $19,17 \%$ \\
\hline Suma końcowa & $30,28 \%$ & $18,64 \%$ & $20,79 \%$ & $11,32 \%$ & $18,98 \%$ \\
\hline
\end{tabular}

Źródło: opracowanie własne na podstawie wyników badań przeprowadzonych wśród studentów MBA na Uniwersytecie Ekonomicznym we Wrocławiu. 
Nowe badanie zostało wzbogacone o dodatkową informację dotyczącą podziału na firmy B2B oraz B2C. Na rys. 2 przedstawiona jest struktura firm według ich przynależności do B2B. Małe firmy, w tej próbie, zdecydowanie przeważają w sektorze B2B. Dodatkowo w branży B2C firmy małe stanowią 100\%.

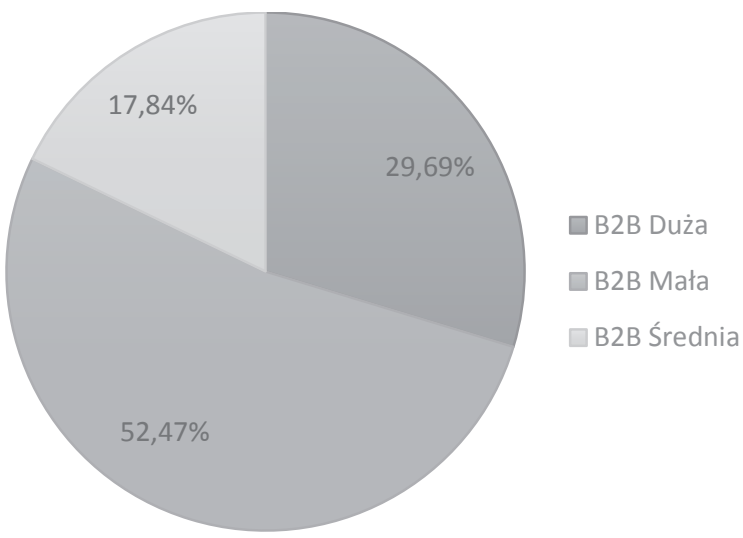

Rys. 2. Struktura firm w sektorze B2B wg ich wielkości (duża, średnia, mała)

Źródło: opracowanie własne na podstawie wyników badań przeprowadzonych wśród studentów MBA na Uniwersytecie Ekonomicznym we Wrocławiu.

Tabela 5 pokazuje, że pomimo $63 \%$ udziału firm B2B w stosunku do firm B2C rozkład wyników w firmach działających w wymienionych relacjach jest bardzo podobny i pokrywa się z myśleniem bardziej klasycznym, aczkolwiek ważne w decyzjach strategicznych jest podejście sieciowe.

Tabela 5. Struktura odpowiedzi podejść do strategii względem relacji biznesowych

\begin{tabular}{|l|l|l|l|l|l|}
\hline $\begin{array}{l}\text { Rodzaj podejścia } \\
\text { do strategii } \\
\text { Relacja } \\
\text { biznesowa }\end{array}$ & Planistyczne & Pozycyjne & Zasobowe & Innowacyjne & Sieciowe \\
\hline B2B & $30,88 \%$ & $18,38 \%$ & $20,97 \%$ & $10,94 \%$ & $18,84 \%$ \\
\hline B2C & $29,26 \%$ & $19,07 \%$ & $20,49 \%$ & $11,97 \%$ & $19,21 \%$ \\
\hline Suma końcowa & $30,28 \%$ & $18,64 \%$ & $20,79 \%$ & $11,32 \%$ & $18,98 \%$ \\
\hline
\end{tabular}

Źródło: opracowanie własne na podstawie wyników badań przeprowadzonych na studentach MBA na Uniwersytecie Ekonomicznym we Wrocławiu. 
Ważnym elementem badania jest również przedstawienie wyników z perspektywy branży, w jakiej działa dane przedsiębiorstwo (tabela 6).

W sektorach $\mathrm{B} 2 \mathrm{~B}$ oraz $\mathrm{B} 2 \mathrm{C}$ kładzie się zdecydowanie nacisk na podejście klasyczne do zarządzania, odpowiednio 70\% i 68\% odpowiedzi. Zauważalny jest również wpływ koncepcji sieciowych w firmach średnich w sektorze B2B, które stanowią niemalże $25 \%$ udziału w całości wyników. Odpowiedzi wskazują ponadto, że firmy z sektora B2C to tylko firmy małe, które cechuje rozkład odpowiedzi podobny do tego dla firm dużych.

Tabela 6. Struktura odpowiedzi podejść do strategii względem branży firmy

\begin{tabular}{|c|c|c|c|c|c|}
\hline $\begin{array}{l}\text { Rodzaj podejścia } \\
\text { do strategii } \\
\text { Relacja } \\
\text { biznesowa } \\
\text { wielkość firmy }\end{array}$ & Planistyczne & Pozycyjne & Zasobowe & Innowacyjne & Sieciowe \\
\hline B2B & $30,88 \%$ & $18,38 \%$ & $20,97 \%$ & $10,94 \%$ & $18,84 \%$ \\
\hline Duża & $27,73 \%$ & $17,08 \%$ & $25,07 \%$ & $10,82 \%$ & $19,30 \%$ \\
\hline Mała & $36,16 \%$ & $19,02 \%$ & $18,20 \%$ & $10,08 \%$ & $16,54 \%$ \\
\hline Średnia & $20,59 \%$ & $18,65 \%$ & $22,25 \%$ & $13,67 \%$ & $24,84 \%$ \\
\hline B2C & $29,26 \%$ & $19,07 \%$ & $20,49 \%$ & $11,97 \%$ & $19,21 \%$ \\
\hline Mała & $29,26 \%$ & $19,07 \%$ & $20,49 \%$ & $11,97 \%$ & $19,21 \%$ \\
\hline Suma końcowa & $30,28 \%$ & $18,64 \%$ & $20,79 \%$ & $11,32 \%$ & $18,98 \%$ \\
\hline
\end{tabular}

Źródło: opracowanie własne na podstawie wyników badań przeprowadzonych na studentach MBA na Uniwersytecie Ekonomicznym we Wrocławiu.

\section{PODSUMOWANIE}

W przedstawionej metodzie uwzględniono bardzo wiele elementów. Przydatna okazała się więc wielowymiarowa analiza porównawcza. Analiza umożliwiła hierarchizację analizowanych podejść do strategii na przestrzeni okresów przeprowadzonych badań, a otrzymane rezultaty porównano z wynikami wcześniej prowadzonych analiz w 2014 roku.

W tabeli 7 został przedstawiony ranking podejść do strategii otrzymany w wyniku dwóch przeprowadzonych przez Autora badań. Podejście pla- 
nistyczne zgodnie z oczekiwaniami zajmuje miejsce numer $1 \mathrm{w}$ rankingu. Podejścia klasyczne, ogólnie zmniejszyły swoje znaczenie w podejmowaniu decyzji w przedsiębiorstwach. Znacznie zmalało znaczenie innowacyjnego myślenia o organizacjach na rzecz podejścia zasobowego. Świadczyć to może o tym, że zasoby firmy w kontekście budowy jej wartości nadal są bardzo ważne dla zarządzających firmami. Owszem są oni świadomi, że innowacje mogą w sposób efektywny wpływać na ich rozwój, aczkolwiek innowacje z reguły oznaczają istotne zmiany, a to z kolei może być zagrożeniem.

Tabela 7. Struktura odpowiedzi podejść do strategii oraz ranking podejść do strategii

\begin{tabular}{|l|c|c|c|c|}
\cline { 2 - 5 } \multicolumn{1}{c|}{} & \multicolumn{2}{c|}{ Struktura podejść do strategii } & \multicolumn{2}{c|}{ Ranking podejść do strategii } \\
\hline Podejście & Badanie z 2014 & Badanie z 2013 & Badanie z 2014 & Badanie z 2013 \\
\hline Planistyczne & $24,51 \%$ & $30,28 \%$ & 1 & 1 \\
\hline Pozycyjne & $21,80 \%$ & $18,64 \%$ & 2 & 4 \\
\hline Zasobowe & $15,88 \%$ & $20,79 \%$ & 5 & 2 \\
\hline Innowacyjne & $19,59 \%$ & $11,32 \%$ & 3 & 5 \\
\hline Sieciowe & $18,22 \%$ & $18,98 \%$ & 4 & 3 \\
\hline
\end{tabular}

Źródło: opracowanie własne na podstawie wyników badań przeprowadzonych na studentach MBA na Uniwersytecie Ekonomicznym we Wrocławiu oraz 66 firmach z różnych branż w Polsce.

Bardzo ważny, o ile nie najważniejszy w zarządzaniu jest wskaźnik rentowności sprzedaży, dlatego dla wzbogacenia analizy, w tabeli 8 zestawiono wyniki wcześniej prowadzonych przez autora badań dotyczące istotności marży w zarządzaniu przedsiębiorstwem.

Wbrew wcześniejszym analizom, przedsiębiorstwa kierują się coraz częściej rentą wynikająca z nadwyżki z tytułu innowacji, o czym świadczy przesunięcie z miejsca 25 na pozycję 6 . Firmy nie są już nastawione na uzyskiwanie marży uzależnionej od popytu na dany produkt - spadek o 5 miejsc. Mówi nam to, że mimo zwiększania w firmie rozmiarów produkcji (skali produkcji), nie zmniejszają się długookresowe przeciętne koszty całkowite (np. koszty energii elektrycznej, reklamy itp.) na tyle, aby uzyskiwać odpowiednio wysokie zyski. 
Pozytywny sygnałem jest stabilna pozycja marży wynikającej z tytułu nadwyżek dzięki kontraktom sieciowym. Dlatego, też przedsiębiorstwa znajdują coraz to większe korzyści z interakcji z otoczeniem.

Tabela 8. Struktura odpowiedzi według marży oraz ranking podejść do strategii dla marży

\begin{tabular}{|l|c|c|c|c|}
\cline { 2 - 5 } \multicolumn{1}{c|}{} & \multicolumn{2}{|c|}{$\begin{array}{c}\text { Struktura podejść do } \\
\text { strategii dla marży }\end{array}$} & \multicolumn{2}{c|}{$\begin{array}{c}\text { Ranking podejść do } \\
\text { strategii dla marży }\end{array}$} \\
\hline Struktura odpowiedzi wg rodzaju marży & $\begin{array}{c}\text { Badanie } \\
\mathbf{z ~ 2 0 1 4}\end{array}$ & $\begin{array}{c}\text { Badanie } \\
\text { z 2015 }\end{array}$ & $\begin{array}{c}\text { Badanie } \\
\text { z 2014 }\end{array}$ & $\begin{array}{c}\text { Badanie } \\
\text { z 2015 }\end{array}$ \\
\hline $\begin{array}{l}\text { Marża firmy uzależniona od popytu na dany } \\
\text { produkt. Wysokość marży wynika z relacji } \\
\text { między popytem a podażą na dany zasób }\end{array}$ & $3,39 \%$ & $4,16 \%$ & 14 & 9 \\
\hline $\begin{array}{l}\text { Marża wynika z udziału firmy w danym } \\
\text { sektorze czy rynku }\end{array}$ & $2,99 \%$ & $4,10 \%$ & 16 & 10 \\
\hline $\begin{array}{l}\text { Marża wynika z nadwyżek uzyskanych } \\
\text { dzięki kontraktom sieciowym. Jednorazowe } \\
\text { kontrakty zwiększają koszty firmy }\end{array}$ & $2,68 \%$ & $2,65 \%$ & 19 & 18 \\
\hline $\begin{array}{l}\text { Marża wynikająca z nadwyżki z tytułu } \\
\text { innowacji - innowacji rozumianej jako } \\
\text { pojawienie się nowych produktów, nowych } \\
\text { źródeł podaży, nowych typów organizacji }\end{array}$ & $0,93 \%$ & $5,26 \%$ & 25 & 6 \\
\hline
\end{tabular}

Źródło: opracowanie własne na podstawie wyników badań przeprowadzonych na studentach MBA na Uniwersytecie Ekonomicznym we Wrocławiu oraz 66 firmach z różnych branż w Polsce.

Sytuacja na rynku wywiera presję na organizacje powodując ograniczenie w sposobie działania. Firmy muszą liczyć się ze stanami braku dostatecznych informacji i niepewności. W związku z tym stworzenie właściwego planu działania jest podstawowym warunkiem sukcesu i przetrwania dla każdego przedsięwzięcia. Niezbędne do tego staje się stworzenie odpowiedniego planu działania, czyli strategii.

Reasumując, w kontekście przedstawionych analiz wydaje się, że nie ma jednej skutecznej strategii. Podejścia klasyczne nadal przeważają nad współczesnymi, które pomimo, że są aktualnie wykorzystywane przez przedsiębiorstwa, musza sobie zasłużyć i zapracować, aby można było je zaliczyć do kanonu wiedzy w zakresie zarządzania strategicznego. Oba współczesne podejścia posiadają duży potencjał, który należy jeszcze do- 
głębniej zbadać, aby móc w pełni wykorzystać nowe myślenie o zarządzaniu oraz implementować je w praktyce gospodarczej.

Przedstawiona metoda oraz kolejne badanie pilotażowe wymaga zweryfikowania go w szerszym gronie firm w danych branżach, aby móc zdecydowanie określić, że przedstawiona metoda identyfikacji podejść do strategii jest narzędziem wystarczającym do określenia obecnie stosowanej strategii oraz czy będzie mogła umożliwić ocenę stanu obecnego oraz wprowadzenie ewentualnych zmian w zarządzaniu. Z kolei słabość przedstawionej metody identyfikacji podejścia do strategii może wynikać z faktu wykorzystania klasycznej ankiety, zbierającej opinie, a nie fakty. W przyszłości Autor planuje wzbogacić metodę o szeroką analizę danych ekonomicznych i organizacyjno-zarządczych mogących wspierać wnioskowanie przedstawione w wyniku zaproponowanej metody identyfikacji podejścia do strategii.

\title{
LITERATURA
}

Gierszewska G., Romanowska M. (2009), Analiza strategiczna przedsiębiorstwa, PWE, Warszawa.

Niemczyk J. (2013), Strategia. Od planu do sieci, UE Wrocław.

Jasiński M., (2015), Metoda identyfikacji podejść do strategii, UE Wrocław.

\section{THE USE OF METHODS OF IDENTIFYING APPROACHES TO STRATEGY STUDIES OF SELECTED COMPANIES}

\begin{abstract}
Strategic management is laying out ways to implement long-term goals of the company. Most often the main objective is to achieve market success. It must therefore be based both on set by the organization determinants of success, as well as on external factors creating market environment. They are important in making such decisions to date information from the market - be they know a good source and verify them with the knowledge and competence. Never, however, we will not have a hard analysis indicating the chances of success of the action. If you do not make attempts to define the current state of the company for the management decisions they take will not be possible to create an objective aimed at solving organizational development. This article aims to build a method by which you will be able to identify a way of thinking about strategy and approach to draw conclusions from the analysis so that you can make informed decisions.
\end{abstract}

Keywords: strategic management; strategy; business management; business; method of identifying approaches to strategy. 